\title{
Conceptualizing Digital Agricultural Governance
}

\author{
Tsehay Wasihun Muluneh \\ College of Computer Science and Information Technology, \\ Sudan University of Science and Technology, \\ Khartoum, Sudan.
}

\begin{abstract}
Digital government (DGov) research studies the use of digital technologies in the public sector to improve the workings of government institutions and relations with citizens. Agricultural governance (AGGOV) research studies the application of effective governance to facilitate growth and development of the agricultural sector. Despite advancements in both domains independently, little research are available at their interaction. This study applied the concept of DGov in support of AGGOV. We call this interaction Digital Agricultural Governance (DAGGOV). The paper first defines DGov by evaluating existing definitions in the domain. Then, it explores governance in the agricultural sector by adopting the six dimensions of World Bank's governance assessment framework. Finally, the paper defines and proposes a conceptual framework for digital agricultural governance (DAGGOV). The main contribution of the paper is establishing a foundation for DAGGOV researches.
\end{abstract}

Keywords - Agricultural governance; Digital agricultural governance; Digital government; Electronic government.

\section{INTRODUCTION}

According to a recent projection, the global population will reach in between 9.4 and 10.2 billion by 2050 [1]. Such a rapid population growth is most difficult to accommodate in the developing world because of slow productivity growth [2]. According to studies, there are various reasons for stagnation and decline of agricultural productivity and rural development in the developing world including low investment, poor rural infrastructure, and corruption [3]; armed conflict [4]; weak regulation and law enforcement [5]; and poor rural infrastructure [6].

Almost all problems such as low investment, infrastructure, corruption, conflict, and weak regulation and enforcement are related to the concept of governance. According to Organization for Economic Co-operation and Development, "governance refers to the formal and informal arrangements that determine how public decisions are made and how public actions are carried out, from the perspective of maintaining a country's constitutional values when facing changing problems and environments" [7].

In the agricultural sector, governance is used to build trust and provides rules and stability needed for agricultural investment, which requires specialized inputs, in the long term [8]. It also supports the provision of agricultural public services and used to build participatory, transparent and accountable agricultural system. It further promotes the free and effective interaction between different stakeholders of the agricultural sector to exchange information significant for agricultural production and product market [8]. However, very little has been achieved particularly in developing countries since the importance of governance on agriculture was recommended in the 1982 World Development Report [9].
Recently, governance processes are supported by digital technologies to help provide public services to citizens in a better way. With the help of innovative digital tools, governments in many parts of the world try to reach citizens at large and provide appropriate services effectively to citizens [10]. Beyond service provision, governments, civil society groups, and development institutions are now increasing public participation through electronic means [10]. Empirical survey studies also witnessed the positive impact of digital technologies in promoting governance [11], [12], \& [13].

Being aware of the significance of governance for rural development and digital technologies for effective governance, this paper applies the concept of digital government to support governance in the agricultural domain- Digital Agricultural Governance (DAGGOV). DAGGOV is the use of digital technologies to enhance governance of the agricultural sector through promoting the internal operation of rural sector institutions, enhancing the delivery of public goods and services, promoting the efficiency of rural market, increasing the participation of the rural poor in government decision- and policy-making processes and others. However, despite promising advancements in the DGov (Digital Government) domain independently, little researches are available in the AGGOV domain. In addition, we are not aware of any efforts to define and conceptualize the DAGGOV domain, to explore the impact of digital government in governance process of the agricultural sector (see appendix A).

This paper fills this important gap by developing a conceptual framework for DAGGOV that helps define the boundaries and dimensions of the domain based on the boundaries and dimensions of the main contributing domains -DGov and AGGOV.

The paper after this introduction is organized into two sections. Section 2 presents a conceptual framework for DAGGOV that helps define the boundaries and dimensions of the domain based on the boundaries and dimensions of the main contributing domains DGov and AGGOV. Section 3 addresses concluding remarks.

\section{CONCEPTUAL FRAMEWORK}

This section introduces a conceptual framework for DAGGOV applied in this paper. The framework is developed step by step starting from DGov (Section 2.1), AGOV (Section 2.2) and finally DAGGOV (Section 2.3).

\section{A. Digital Government (DGov)}

With the advancement of ICT (Information, Communication Technology) particularly the internet and its application in public sector, words like Electronic Government (e-Government) have come into practice [14]. 
Recently, terms like Electronic Governance; Digital Government; and Digital Governance are commonly used in the e-Government domain. However, there is no uniformity and clarity in referring to electronic government and its digital version, digital government. For example, [15], [16], \& [17] refers to Electronic Government and Digital Government synonymously and they define Electronic Government or Digital Government as:

- "Government's use of information technology to exchange information and services with citizens, businesses, and other arms of government" [15, p. 294).

- "The provision of information and online transaction kinds of services to citizens in a state by the government" [16, p. 371].

- "The application of information and communication technologies (ICTs) to improve public services and to increase citizen participation in democratic government" [17, p.3].

On the other hand literatures like [18], [19], \& [20] refers to Electronic Government and Digital Government as two different stages in the evolution of technology use by government. They define Electronic Government as:

- "The use of digital technology, particularly the internet, by government to achieve better government" $[18$, p. 6]

- "The production and delivery of government services through technology applications" $[19$, p. 3]

- "The use of IT to deliver public services efficiently" [20, p. 10].

They also define Digital Government as the use of modern information communication technology or digital technology to:

- "enable governments to create increased public value and broad public sector modernization (with greater openness, transparency, engagement with and trust in government)" [18, p. 6].

- "facilitate the exchange information and process transactions across networks" [19, p. 4]

- "address key transformational issues such as the adoption of citizen-driven model, new governance mode based on open government principles, Data Potential Unlocking, digital by default imperative and digital security challenges" [20, p.15].

OECD further pointed out the difference between Electronic Government and Digital Government as a part of the digital transformation path comprising three evolutional stages- Digitization, Electronic Government, and Digital Government as depicted in table 1 [21]. Digitization is the first stage in the digital transformation path and mainly focuses on the adoption of digital technologies (generally
ICT) by government to improve efficiency and productivity of a government. The second stage is Electronic Government, in this stage digital technologies are utilized to improve organizational environment within the government. The final stage in the digital transformation path is, Digital Government, centered on citizen engagement in the design and overall decision making process.

As we observe from the above definitions of Electronic Government and Digital Government, literatures in the first category ignore the differences between the two terms emanated from the technological perspective and use the two terms interchangeably. From a technological perspective electronic and digital are not completely similar. The term electronic is used in broader sense than digital. Electronic refers to all types of information communication devices (ICT). These include older technologies, such as radio, television and video and newer ones, such as computers, mobile phones and the internet [22]. The later, digital, is particularly referring to new information communication technologies (ICT) that operate digitally [22].

Whereas, in the second category of literatures the two terms are considered different, and Electronic Government is more concerned on transforming operations internal to government while Digital Government is about strengthening external relationships with customers and all other involved stakeholders. Based on such context, Electronic Government and Digital Government directly overlapped in to the two consecutive stages in the evolution of technology use by government such as "Electronic Government" and "Electronic Governance" respectively. Electronic Government is the preceding stage in the evolution and more limited to government organizations internal operation [14], [23], [24], [25] \& [26]. Whereas, Electronic Governance is broader than Electronic Government and encompassing concept that involves multiple stakeholders including citizens, private businesses and the society in addition to government [23], [25], \&[26]. But, in practice the difference between Electronic Government and Digital Government is not identical with the differences in Electronic Government and Electronic Governance. The difference between Electronic Government and Digital Government is by the type of technologies adopted by a government.

In General, Electronic Government and Digital Government are not synonymous from the technological perspective as well as the difference between the two terms is not evolutional. The main difference between Electronic Government and Digital Government is about the range of technologies/ICTs adopted by government. The term digital is more appropriate to refer to modern technologies. 
Table I: The Elements of Digital Transformation

Information and Communication Technologies

$\begin{array}{lll}\text { Digitization } & \text { Electronic Government } & \text { Digital Government } \\ \text { (greater use of digital technologies } & \text { (use by governments of digital } & \text { (Digital technologies and user preferences } \\ \text { to improve cross government } & \begin{array}{l}\text { technologies, particularly the } \\ \text { integrated in the design and receipt of }\end{array} \\ \text { activities and data linformation } & \begin{array}{l}\text { Internet, to achieve better services and broad public sector reform - } \\ \text { government) }\end{array} & \begin{array}{l}\text { integral part of governments'modernization } \\ \text { strategies to create public value) }\end{array}\end{array}$

Change Path

\begin{tabular}{llll}
\hline $\begin{array}{l}\text { From a focus on: efficiency and } \\
\text { productivity }\end{array}$ & $\begin{array}{l}\text { Through a focus on: efficiency } \\
\text { and productivity in delivering } \\
\text { tailored services to individuals }\end{array}$ & $\begin{array}{l}\text { To a focus on: governance, (openness, } \\
\text { transparency, engagement with and trust in } \\
\text { government), as well as efficiency and } \\
\text { productivity }\end{array}$ \\
\hline $\begin{array}{l}\text { From Government-centered } \\
\text { users }\end{array}$ & $\begin{array}{l}\text { Through User/Citizen-centered }- \\
\text { users participate in service } \\
\text { passive recipients of services }\end{array}$ & $\begin{array}{l}\text { To People-driven }- \text { users voice their } \\
\text { demands and needs, contribute to shaping } \\
\text { the agenda and services'content and } \\
\text { delivery }\end{array}$ \\
\hline
\end{tabular}

Digital Transformation

Considering the discussion given above and the definition of Electronic Governance in [27, p.6], we suggest the following definition for Digital Government (DGov).

Digital government is the application of digital technologies (modern ICT) by government to transform operations internal to government and the relation with citizens to create various benefits for society.

The definition clearly identifies three key solution dimensions of digital government. They are: government/institution, technology and citizens. For this study the government dimension refers to the implementing institutions. It includes governmental and non-governmental organizations, associations, enterprises, companies, and businesses concerning their roles, function, views etc. The technology dimension refers to infrastructures of hardware, software/applications and services; and citizen- refers to rural residents regarding their roles, views, needs and aspirations. The three dimensions are meant to cover the whole DGov solution space but the list of elements under each dimension is open-ended.

\section{B. Governance in the Agricultural sector (Agricultural Governance)}

Governance is defined as "the manner in which public power is exercised in the management of a county's economic and social resources for development" [28, p.1]. It comprises mechanisms, processes and institutions through which citizens and groups articulate their interests, exercise their legal rights, meet their obligations and mediate their differences [29].

The term governance was not common in the development context before the 1989 World Bank's report [30]. But, in recent few decades, the concept of governance is highly recognized in the development circle [8].

Upgrading the agricultural sector from the good governance perspective is a new and effective approach to enhance agricultural sector growth and productivity [31]. It is defines agricultural governance as: the augmentation of growth and development of a country's agriculture sector and managing the consequences of this process through the effective functioning of its institutions, the application of technology and scientific innovations, the implementation of policies, adherence to acts and regulations, and active participation of all involved stakeholders. [32, P.3]

There has been a growing interest in the effect of governance on agricultural performance. For example, [8]; [33]; and [5] examine the relationship between governance and agricultural performance. According to the findings of these studies, there exists a positive correlation between governance and agricultural productivity.

Furthermore, international organizations like International Fund for Agricultural Development (IFAD) utilize a rural sector performance assessments (RSP) framework to assess the status of rural governance infrastructures for allocation of funds. The framework is based on five dimensions of governance for rural development-sectors [34]. In 2016, CARE international also undertakes governance assessments of the agricultural sector in Egypt, particularly in agricultural Extension and Cooperation section. However, these assessments are designed to measure the status of governance in the rural sector and the indicators are not suitable to measure the impact of governance in the rural sector [32].

Here we adopt the six aggregate World Bank indicators known as "Worldwide Governance Indicator (WGI)" [35], with respect to the agricultural sector context. These indicators combine the views of a large number of enterprises, citizen and expert survey respondents in industrial and developing countries [32]. In addition, the dimensions of WGI are not narrowly focused and they are the best way to summarize a very large number of indicators from varying perspectives. They are also tested in the agricultural sector in relation to productivity [8] \& [33].

The six dimensions of WGI are defined as: 
1. Voice and accountability (VA): This dimension concerns the extent to which citizens are able to participate in selecting their government, as well as enjoy freedom of expression, freedom of association, and free media.

2. Political stability and absence of violence (PV): This dimension concerns the perceptions of the likelihood that government may be destabilized or overthrown by unconstitutional or violent means, including terrorism.

3. Government effectiveness (GE): This dimension concerns the quality of public services, the quality of civil service and its independence from political pressures, the quality of policy formulation and implementation, and the credibility of government's commitment to such policies.

4. Regulatory quality (RQ): This dimension concerns government's ability to formulate and implement sound policies and regulations that permit and promote private sector development.

5. Rule of law (RL): This dimension concerns the extent to which government agents have confidence in and abide by the rules, and in particular the quality of contract enforcement, as well as the likelihood of crime and violence.

6. Control of corruption (CC): This dimension concerns the extent to which public power is exercised for private gain, including both petty and grand forms of corruption, as well as the "capture" of the state by elites and private interests.

In the following sections, we explore the six dimensions of governance and their effect on the agricultural sector.

1) Dimension 1: Voice and accountability (VA): This dimension measures the extent of citizen's participation in selecting their government, forming associations, as well as freedom of expression and free media. In the agriculture sector, this dimension is concerned with the extent of farmers' participation in selecting their representatives and their bargaining power on agricultural policy development that determines budget allocations, agricultural taxation, subsidization, and the provision of public good and agrarian relations [36]. Participation is defined as a direct involvement of farmers and marginalized groups in the decision making process [37]. It is an important factor for sustainable agriculture in rural area [37]. However, the participation of rural poor is very limited even in democratic systems [38]. There are a number of reasons why participation is hard to achieve in practice. In rural area of the developing world, participation is constrained by a number of factors, including lack of effective and strong government institutions, lack of infrastructure, lack of information, and knowledge [39].

The freedom of interaction between farmers and all other stakeholders is another element under the umbrella of the first dimension. The freedom of interaction between farmers and other stakeholders such as farmers' unions or grass-roots groups help form different organizations and farmers' voice can be better heard and represented through the organizations [40]. The free media can also play a significant role in promoting the voice of disadvantaged groups in the policy making process and strengthening the accountability of governments to rural citizens. Accountability can be strengthened through disseminating government rules, procedures, its performance data and through disclosing public assets and procurement information to a wider rural community. In addition, the publicity and access of such kind of information can help to fight corruption [42].

2) Dimension 2: Political stability and absence of violence $(P V)$ : This dimension measures perceptions of the likelihood that the government will be destabilized or overthrown by unconstitutional or violent means, including terrorism. Peace and stability are important components of effective governance. The absence of peace and stability restricts the free movement of citizens, transportation of resources from one place to the other and engaging in production activities. Those restrictions directly affect the production and productivity of the agricultural sector that requires different production resources and an involvement of different stakeholders and effective interaction between them [33]. According to research studies, yearly agricultural revenues per hectare and investments are lower in regions with an intense conflict [4]. As conflicts result in immediate increase in production costs, lower access to formal financial institutions, and lower investments, they directly impact agricultural production systems [4].

Political instability can also frustrate private investment as it directly or indirectly threatens the security of such investment. It is also likely to influence the characteristics of public investments [36].

3) Dimension 3: Government effectiveness (GE): This dimension refers to the government's capacity for formulating and implementing good agricultural policies, and the provision of agricultural goods and services [8]. The quality of agricultural policy is critical for agricultural development. Data is a major input for policy formulation. Agricultural data can be hugely available but its quality matters effective policy formulation. The quality of data is determined by the way the data is collected, generated and synthesized. Developing countries are in the lowest rank regarding the quality of data [43].

The quality in the provision of agricultural goods and services is another critical element for agricultural development. It involves the delivery of raw materials, roads, irrigation systems, communications infrastructure, schools, and agricultural research and extension services [44]. However, because of distance, limited resources, low human capacity, and widespread poverty, providing these services to rural citizens is not easy in developing countries [10].

4) Dimension 4: Regulatory quality $(R Q)$ : The regulatory environment lays the foundation up on which farmers, input suppliers and other agricultural businesses operate and make investment decisions [45]. It determines the level of agricultural investment, technological development, and innovations.

Protectionism and price control is one way to explain the effect of government policies and regulations on agriculture. An important example is the case of Philippines prior to 1980s. The Philippines Government enacted laws that protected the import of agricultural products, imposed high export taxes, and limited the participation of the private sector in agricultural input supply. In addition, by establishing the National Food Authority, the government 
tried to control agricultural commodity prices. However, many government programs established with the aim of protectionism resulted to higher prices of agricultural products and discouraged new investment. In contrary, the 1986 reform reduced the government's monopolistic power; eliminated export taxes on agriculture and quantitative restrictions and traffic on agricultural inputs; and offered farmers the opportunity to either adopt more efficient or productive methods, or to shift to more profitable crops [46].

Not only protectionism and price control discourage private agricultural investment but the quality of services in the investment processes also matters. Like other business investments, private agricultural investment requires registrations, taxes, licenses, and completion of other business processes [10].Thus, delays in bureaucratic procedures discourage private investments [10].

5) Dimension 5: Rule of law (RL): This dimension measures how well public institutions are respected by citizens and government agents, the capacity of government agents in enforcing contracts, and how well the justice system serves farmers in rural areas. Without proper protection of property rights and law enforcement, major private investments could not take place in the agricultural sector in which productivity is highly dependent on investment [8]. According to [32], "secured land rights are one of a key determinant of farmers' willingness to invest in resources and use new technologies to improve the productivity of smallholder agriculture". Therefore, governance interventions to improve security of land rights are primarily focused on improving security of land tenure. The process and security of land tenure can be facilitated and enhanced by modernizing land administration through [32]:

- Simplifying the process of registering and transacting land rights;

- Using technological tools to document land-related issues, i.e. registrations, transactions, demarcations and allocations;

- Decentralizing land administration and management to local authorities;

- Updating regulatory frameworks and strengthening judiciary for enforcement of land rights and imposition of sanctions; and

- Building transparent and accountable service provision on land sector administration.

Similarly, the efficiency of judicial system in resolving disputes is another important element that directly affects private investment. A recent study analyzing 98 developing economies suggests that foreign direct investment tends to be greater where the cost of contract enforcement in debt collection and property eviction cases is lower [47].

6) Dimension 6: Control of corruption $(C C)$ : This dimension measures to what extent the political and executive power is exercised for private gain. It is important to identify different types of corruption to understand and group corrupt activities mostly encountered in the agricultural sector. Corrupt activities include petty bureaucratic corruption (i.e. low-level administrative corruption), self-serving asset stripping by state officials (state capture) and large political corruption (grand corruption) [48]. Corruption in small-scale agriculture is diverse and includes granting land titles, credit availability, quality of supplies and water source allocation [32].

In developing countries, corruption is widely spread in land administration and management activities. The land administration activities that most expose farmers to corruption include land titling, demarcation of boundaries, processing of land transactions and valuation exercises [49]. In India, farmers frequently pay bribes (from $20 \%$ to $90 \%$ of transaction values) to obtain land administration-related services [50]. Similarly in Ethiopia, bribery and informal fees occur in public land transactions concerning large - scale agricultural investments [51] \& [52]. For example, according to the 2010/2011 Global Corruption Barometer, 50\% of the respondents reported having paid a bribe to land services [51]. Corruption is widespread due to the lack of clear policies, weak institutions, lack of transparency, limited public participation, and capacity challenges [52].

The presentation above explores the six dimensions of governance according to the agricultural sector. This study defines the dimensions of governance in context of the agricultural sector as shown in Table II.

\section{Digital Agricultural Governance (DAGGOV)}

Based on the definitions of DGov suggested in section 2.1 and of AGGOV in [32], we also propose the following comprehensive definition of DAGGOV:

Digital Agricultural Governance (DAGGOV) is the application of digital technologies (modern ICT's) to transform internal functioning of rural institutions, the delivery of agricultural goods and services, and the interaction between government and the rural public with enhanced transparency, accountability, regulation and contract enforcement, and active participation of all involved stakeholders aiming to ensure growth and development of the agricultural sector.

Fig. 1 depicts possible conceptual model for DAGGOV. In the model DGov is depicted at the intersection of institution, technology and citizens, representing the three solution dimensions involved. AGGOV is depicted at the intersection of voice and accountability (VA), political stability and absence of violence (PV), government effectiveness (GE), regulatory quality (RQ), rule of law (RL), and control of corruption (CC) representing the six dimensions of agricultural governance to be impacted by a DGov solutions. Finally, DAGGOV is depicted at the intersection of Digital Technology (DT), Governance (GOV) and Agriculture (AG), representing technology-enabled governance of the agricultural sector. In addition, the secondary domains are formed by intersections of any two domains: Digital Governance (DGOV) is at the intersection of GOV and DT, DT for Agriculture (DT4AG) is at the intersection of DT and AG, and Agricultural Governance (AGGOV) is at the intersection of GOV and AG.

Furthermore, there is a relationship between contributing domains of the DAGGOV domain. The type of relationship between domains is unilateral; one domain (solution) helps to satisfy the goals of another domain (customer). Agriculture is always a customer domain in any relationship; DT is always a solution domain, while GOV is a customer domain in relationship to DT and solution domain in relationship to 
Agriculture. In the case of DAGGOV, AGGOV is the customer domain and DGOV is the solution domain.

Table II: Defining the dimensions of Governance

\begin{tabular}{|ll|}
\hline Governance Dimensions & Definition \\
\hline Voice and accountability (VA): & $\begin{array}{l}\text { Farmers and other stakeholders' participation in all of the stages of decision making of } \\
\text { the agricultural sector including in selecting their representatives and expressing } \\
\text { opinions, as well as the freedom of interaction and forming farmers association. }\end{array}$ \\
\hline Political stability and absence of violence (PV): & $\begin{array}{l}\text { The likelihood of political conflict and the extent of violence and criminality in rural } \\
\text { areas. }\end{array}$ \\
\hline Government effectiveness (GE): & $\begin{array}{l}\text { Capacity of the agricultural sector in policy formulation and the provision of agricultural } \\
\text { goods and services. }\end{array}$ \\
\hline Regulatory quality (RQ): & $\begin{array}{l}\text { The quality of agricultural development policies and regulations towards promoting } \\
\text { private sector agricultural investment, technological development and innovation. }\end{array}$ \\
\hline Rule of law (RL): & $\begin{array}{l}\text { Accessibility and quality of the justice system and enforcement of contracts and rights to } \\
\text { land, water etc. }\end{array}$ \\
\hline Control of corruption $(\mathbf{C C}):$ & The extent to which agricultural public power is abused for private gain. \\
\hline
\end{tabular}

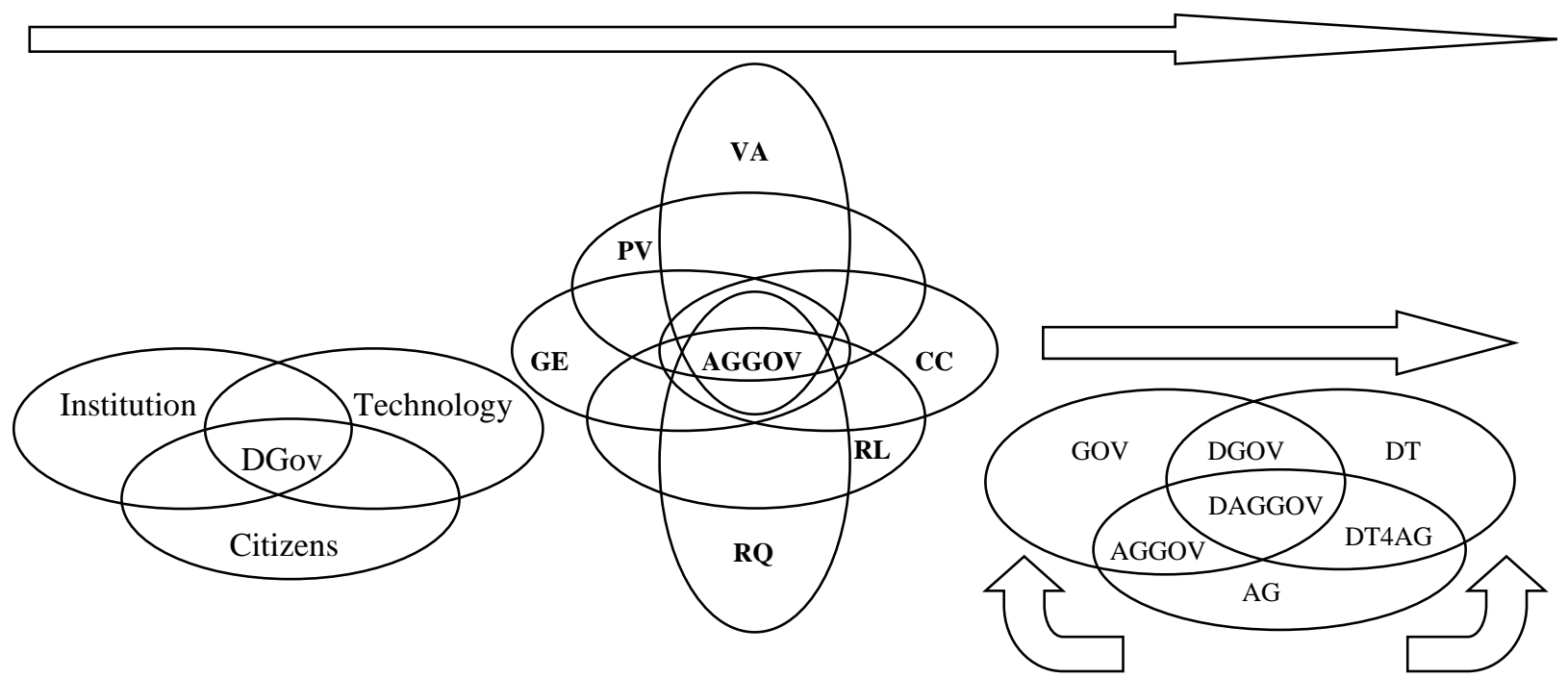

Figure 1: Conceptual Model of DAGGOV

\section{CONCLUSION}

We expect that the elaborated conceptualization of digital agricultural governance in this paper will contribute to future studies. In order to progress in new multi-disciplinary research areas like Digital Agricultural Governance (DAGGOV), there is a need to build a good understanding of the underlying concepts. To fulfill this need, this paper presented a conceptual framework for DAGGOV building upon a conceptualization of DGov and existing AGGGOV models. The framework identified three dimensions in the DGov perspective - institution, technology, and citizen; five dimensions in the AGGOV perspective - voice and accountability, political stability and absence of violence, government effectiveness, regulatory quality, rule of law and control of corruption; and six underlying domains Governance (GOV), Agriculture (AG), Digital Technology (DT), Digital Governance (DGOV), Governance for AG (GOV4AG), and DT for AG (DT4AG). In order to discuss digital agricultural governance initiatives or concepts one needs to consider the six dimensions of governance.
The main contribution of the paper is to build a good understanding of the DAGGOV domain, and to establish a foundation for further DAGGOV research. The paper discovered that despite the growing interest in DGov and AGGOV research and a strong potential for applying DGov research to further AGGOV goals, research at the crossroads of both domains is limited and almost completely practiced within the contributing domains. In our future work, we plan to develop a DAGGOV impact assessment framework, identify the impact of digital agricultural governance with case studies, and finding correlations between impacts and solutions. 


\section{Appendix}

\begin{tabular}{|c|c|c|c|c|c|c|c|c|c|c|c|c|}
\hline \multirow[t]{2}{*}{ Domains } & \multicolumn{12}{|l|}{ Years } \\
\hline & 2008 & 2009 & 2010 & 2011 & 2012 & 2013 & 2014 & 2015 & 2016 & 2017 & 2018 & 2019 \\
\hline$\overline{\mathrm{AG}}$ & 23234 & 26139 & 29951 & 32412 & 35686 & 38346 & 40570 & 41413 & 38461 & 36861 & 39123 & 40154 \\
\hline GOV & 13582 & 15667 & 17674 & 19749 & 21559 & 23336 & 24154 & 25067 & 24368 & 23379 & 22774 & 23460 \\
\hline DT & 74 & 108 & 114 & 146 & 111 & 191 & 186 & 228 & 272 & 340 & 406 & 487 \\
\hline DGox & 53 & 35 & 36 & 44 & 28 & 35 & 29 & 42 & 52 & 75 & 100 & 173 \\
\hline AGGOV & 4 & 3 & 4 & 2 & 5 & 4 & 4 & 4 & 5 & 0 & 5 & - \\
\hline DT4AG & 6 & 7 & 7 & 16 & 9 & 16 & 14 & 22 & 13 & 19 & 11 & 18 \\
\hline DAGGOV & 0 & 0 & 0 & 0 & 0 & 0 & 0 & 0 & 0 & 0 & 0 & 0 \\
\hline
\end{tabular}

Table 3 presents the number of papers published in the DAGGOV domain as searched from Microsoft Academic database. According to the DAGGOV conceptual framework, we considered three primary domains-GOV, AG and DT, three secondary domains-DGov, AGGOV and DT4AG, and the DAGGOV domain itself. The search was based on the appearance of a set of keywords in the titles, abstracts and keywords of the papers published between 2008 and 2019. For each domain, the following keywords were used:

1. GOV - Governance

2. AG - Agriculture

3. DT - Digital Technology

4. DGov - Digital Government

5. AGGOV - Agricultural Governance

6. DT4AG - Digital Technology for Agriculture (Note: No literatures are available for a key word "Digital Technology for Agriculture" and we use "ICT for Agriculture" and retrieved the stated number of literatures)

7. DAGGOV - Digital Agricultural Governance.

\section{REFERENCE}

[1] UN-United Nation. (2017). World population prospects: the 2017 revision, key findings and advance tables. Department of Economics and Social Affairs PD, editor. New York: United Nations. Available at: https://esa.un.org/unpd/wpp/publications/files/wpp2017_keyfindin gs.pdf

[2] Dasgupta, M., Bongaarts, J., \& Cleland, J. (2011). Population, poverty, and sustainable development: A review of the evidence. The World Bank.

[3] Nchuchuwe, F. F., \& Adejuwon, K. D. (2012). The challenges of agriculture and rural development in Africa: the case of Nigeria. International Journal of Academic Research in Progressive Education and Development, 1(3), 45-61. Available at:

https://www.researchgate.net/publication/325909370_The_Challen ges_of_Agriculture_and_Rural_Development_in_Africa_The_Cas e_of_Nigeria.

[4] Arias, M. A., Ibáñez, A. M., \& Zambrano, A. (2012). Agricultural Production amidst Conflict: The Effects of Shocks. Uncertainty and Governance of Non-State Armed Actors. Available at https://web.worldbank.org/archive/website01589/WEB/IMAGES/ ANDRES-2.PDF.

[5] Bayyurt, N., \& Y1lmaz, S. (2012). The impacts of governance and education on agricultural efficiency: An international analysis. Procedia-Social and Behavioral Sciences, 58, 1158-1165. DOI: 10.1016/j.sbspro.2012.09.1097.

[6] Llanto, G. M. (2012). The impact of infrastructure on agricultural productivity (No. 2012-12). PIDS Discussion Paper Series.
[7] OECD- Organization for Economic Co-operative Development. (2011). Policy framework for investment User's Toolkit. Chapter 10. Public Governance. Available at http://www.oecd.org/investment/toolkit/policyareas/publicgoverna nce/41890394.pdf.

[8] Lio, M., \& Liu, M. C. (2008). Governance and agricultura productivity: A cross-national analysis. Food Policy, 33(6), 504512. DOI: 10.1016/j.foodpol.2008.06.003.

[9] UNEP-United Nation Environmental Program. (2008) Governance and Agriculture. Bonn, Germany. Available at http://www.un.org/en/ecosoc/docs/pdfs/governance.pdf.

[10] George, T., Bagazonzya, H., Ballantyne, P., Belden, C., Birner, R., Castello, R. D., \& Treinen, S. (2011). ICT in agriculture: connecting smallholders to knowledge, networks, and institutions (No. 64605, pp. 1-428). The World Bank. Gopakumar, K. (2001). Increasing Information access to improve political accountability \& participation, 3rd annual conference of the ABD/OECD Anti-corruption initiative for Asia Pacific, Tokyo, Japan, 28-30 November, 2001.

[11] Batista, C. (2003). ICTs and good governance: the contribution of information and communication technologies to local governance in Latin America. Brazil: Brazil University.

[12] Raghupathi, W., \& Wu, S. J. (2011). The relationship between information and communication technologies and country governance: An exploratory study. Communications of the Association for Information Systems, 28(1):181-198. DOI: $10.17705 / 1 C A I S .02812$.

[13] Srivastava, N. (2015). E-Governance in rural India. International Journal of Computer Science and Information Technologies, 6(1), 741-744. Available http://ijcsit.com/docs/Volume\%206/vol6issue01/ijcsit2015060116 5.pdf

[14] Grönlund, Å., \& Horan, T. A. (2005). Introducing e-gov: history, definitions, and issues. Communications of the association for $\begin{array}{llr}\text { information } & \text { systems, } 15(1), & 39,\end{array}$ DOI: 10.17705/1CAIS.01539.

[15] Kumar, M., \& Sinha, O. P. (2007). M-government-mobile technology for e-government. In International conference on $e$ government, India (pp. 294-301). Available at: http://citeseerx.ist.psu.edu/viewdoc/summary?doi=10.1.1.394.228 4.

[16] Garg, H. (2016). Digital governance. International Journal of Humanities and Management Sciences, 4(4), 371-374. Available at: http://www.isaet.org/images/extraimages/UH0916112.pdf.

[17] Davies, R. (2015). e-Government: Using technology to improve public services and democratic participation. European Parliamentary Research Service.

[18] OECD- Organization for Economic Co-operative Development. (2014). Recommendation of the council on digital government strategies. Public Governance and Territorial Development Directorate. Available at: https://www.oecd.org/gov/digitalgovernment/Recommendation-digital-government-strategies.pdf.

[19] Delorme, R. (2016). Digital Strategies in Local Government: Private Sector and Early Adopters Lessons Learned.

[20] Bounabat, B. (2017). From e-government to digital Government. Electronic Journal of Information Technology, 8-21. 
[21] OECD. (2016). Digital Government Strategies for Transforming Public Services in the Welfare Areas. Available in http://www.oecd.org/gov/digital-government/Digital-GovernmentStrategies-Welfare-Service.pdf

[22] Cummings, C., \& O’Neil, T. (2015). Do digital information and communications technologies increase the voice and influence of women and girls. A rapid review of the evidence. Overseas Development Institute.

[23] Bernhard, I. (2014). E-government and E-governance: Local Implementation of E-government Polices in Sweden (Doctoral dissertation, KTH Royal Institute of Technology)

[24] Saparniene, D. (2013). From e-Government to e-Governance: eInitiatives in Europe. In Regionalization and Inter-region Cooperation 21 st International NISPACee Annual Conference (pp. 88-106).

[25] Al Athmay, A. A. A. R. A. (2015). Demographic factors as determinants of e-governance adoption: a field study in the United Arab Emirates (UAE). Transforming Government: People, Process and Policy, 9(2), 159-180. DOI: 10.1108/TG-07-20140028.

[26] Janowski, T. (2015). Digital government evolution: From transformation to contextualization. Government Information Quarterly 32(3):221-236. DOI: 10.1016/j.giq.2015.07.001.

[27] OECD. (2014). Recommendation of the council on digital government strategies. Public Governance and Territorial Development Directorate.

[28] World Bank. (1991). Managing Development: the Governance Dimension, a Discussion Paper. World Bank. Available at: http://documents1.worldbank.org/curated/en/88411146813471053 5/pdf/34899.pdf.

[29] UNDP-United Nations Development Program. (1997). Governance for sustainable human development: A UNDP policy document. United Nations Development Program.

[30] World Bank. (1994). Development in practice: The World Bank experience. Available at: http://documents.worldbank.org/curated/en/711471468765285964/ pdf/multi0page.pdf

[31] CARE- Cooperative for Assistance and Relief Everywhere. (2016). Governance Assessment of the Agricultural Sector in Egypt Agricultural Extension and Cooperation. CARE International, Egypt. Accessed from https://www.care.at/wpcontent/uploads/2017/05/Governance-Assessment-of-theAgricultural-Sector-in-Egypt-English.pdf.

[32] Dasgupta, S., \& Roy, I. (2011). Good agricultural governance: a resource guide focused on smallholder crop production. RAP Publication, (2011/18)

[33] Mandemaker, M., Bakker, M., \& Stoorvogel, J. (2011). The role of governance in agricultural expansion and intensification: global study of arable agriculture. Ecology and Society, 16(2). http://dx.doi.org/10.5751/ES-04142-160208

[34] IFAD-International Fund for Agricultural Development. (2003). The structure and operation of a performance-based allocation system for IFAD: Executive Board - Seventy-Ninth Session. Rome, 10-12 September 2003. Available at: https://webapps.ifad.org/members/eb/79/docs/EB-2003-79-R-2Rev-1-C-R-P-3.pdf?attach=1.

[35] Kaufmann, D., \& Kraay, A. (2002). Growth without Governance, World Bank Policy Research (No. 2928). Working Paper.

[36] Binswanger, H. P., \& Deininger, K. (1999). Explaining agricultural and agrarian policies in developing countries. The World Bank.

[37] Aref, F. (2011). Farmers' participation in agricultural development: The case of Fars province, Iran. Indian Journal of science and Technology, 4(2), 155-158. DOI: $10.17485 / \mathrm{ijst} / 2011 / \mathrm{v} 4 \mathrm{i} 2 / 29952$.

[38] Birner, R. (2007). Improving governance to eradicate hunger and poverty. Twenty twenty (2020) focus brief on the world's poor and hungry people/International Food Policy Research Institute (IFPRI).

[39] Cole, S. (2006). Information and empowerment: The keys to achieving sustainable tourism. Journal of sustainable tourism, 14(6), 629-644. DOI: 10.2167/jost607.0.

[40] Burgess, S. F. (1997). Smallholder voice and rural transformation: Zimbabwe and Kenya compared. Comparative Politics, 127-149.
[41] Norris, P. (2004). Giving voice to the voiceless: Good governance, human development and mass communications.

[42] Kandhro, D., \& Pathrannarakul, P. (2013). The role of technology in enhancing transparency and accountability in public secto organizations of Pakistan. International Journal of Economics Business and Management Studies, 2(1), 20-24. Available at: https://papers.ssrn.com/sol3/papers.cfm?abstract_id=2196811.

[43] Nyirenda-Jere, T., \& Kazembe, J. (2014). Improving Policymaking for Agricultural and Rural Development in Africa The role of ICTs and Knowledge Management. London: International Institute for Environment and Development (IIED) http://pubs. iied. org/pdfs/14636IIED. pdf.

[44] Fan, S., Jitsuchon, S., \& Methakunnavut, N. (2004). The importance of public investment for reducing rural poverty in middle-income countries: The case of Thailand(No. 580-201639362).

[45] OECD- Organization for Economic Cooperation and Development. (2015). Analyzing Policies to Improve Agricultural Productivity Growth, Sustainably. OECD Publishing. Available at: http://www.oecd.org/agriculture/topics/agricultural-productivityand-innovation/documents/analysing-policies-to-improveagricultural-productivity-growth-sustainably.pdf.

[46] Martinez, Juan E. (2013). Governance in Agriculture and Rural Development Available https://www.ombudsman.gov.ph/UNDP4/wpcontent/uploads/2013/01/Chap5.pdf.

[47] Ahlquist, J. S., \& Prakash, A. (2010). FDI and the costs of contract enforcement in developing countries. Policy Sciences, 43(2), 181 200. DOI: $10.1007 / \mathrm{s} 11077-009-9093-3$.

[48] Pathak, R. D., Singh, G., Belwal, R., \& Smith, R. F. I. (2007). Egovernance and corruption-developments and issues in Ethiopia. Public Organization Review, 7(3), 195-208. DOI: 10.1007/s11115-007-0031-6.

[49] Hall, R., Scoones, I., \& Henley, G. (2016). Strengthening land governance: Lessons from implementing the voluntary guidelines. LEGEND State of the Debate Report.

[50] Bhatnagar, S. C. (2014). Public service delivery: Role of information and communication technology in improving governance and development impact. Asian Development Bank Economics Working Paper Series, (391).

[51] Lindner, S. (2014). Ethiopia: Overview of corruption in land administration. Transparency International, 9, 1-11. Available at: https://www.u4.no/publications/ethiopia-overview-of-corruptionin-land-administration.pdf.

[52] Tamrat, I. (2010, April). Governance of large scale agricultural investments in Africa: The case of Ethiopia. In World Bank Conference on Land Policy and Administration, Washington, DC April (pp. 26-27) 